\title{
Adsorption of cadmium onto illite modified by Bacillus mucilaginosus
}

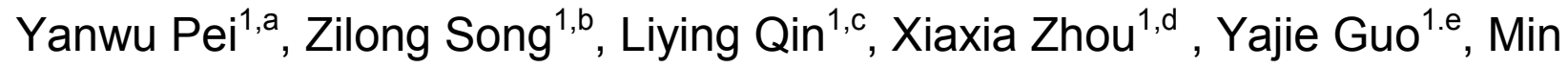 \\ $\mathrm{Wu}^{1 . f}$, Jianchao Hao ${ }^{1, g}$, Xianzhi $\mathrm{Lu}^{1, \mathrm{~h}}$
}

${ }^{1}$ College of Agronomy and Resources \&Environment; Tianjin Engineering Research Center of Agricultural Ecological \& Remediation; Tianjin Agricultural University, Tianjin 300384, China;

aemail:1415645334@qq.com, ${ }^{\text {bemail:2905169757@qq.com, }{ }^{c} e m a i l: 13672117519 @ q q . c o m, e m a i l: ~}$ 2210553867@qq.com, ${ }^{\mathrm{e} e m a i l: 524034354 @ q q . c o m,{ }^{\dagger} \mathrm{email}: 1597137633 @ q q . c o m,{ }^{\mathrm{g}} \mathrm{email}: q q h j c 1980}$

@163.com, corresponding author, ${ }^{\mathrm{h}} \mathrm{email}: \mathrm{nxylxz@163.com}$

KEY WORDS: Cadmium; illite; adsorption; adsorption kinetics; adsorption isotherm

ABSTRACT: Bacillus mucilaginosus was cultured in the medium containing illite, then the culture was burned in muffle to prepare adsorption material modified by microorganism. The biological modified illite (BMI) was used to adsorb cadmium ions at different conditions. The result showed that BMI had significantly improved Cd adsorption potential compared to original illite; BMI had a good adsorption in the neutral environment; adsorption isotherms of $\mathrm{Cd}$ onto BMI followed Langmuir equation and adsorption kinetic of $\mathrm{Cd}$ on $\mathrm{BMI}$ followed pseudo-second order kinetic equation. Fast adsorption of BMI and its environmental friendly implied that the BMI has good prospects for application in practice.

\section{INTRODUCITON}

Heavy metals-contaminated soil has become global environmental concern, heavy metals pose a potential threat to soil ecosystem for its concealment, irreversibility and persistence. Heavy metals will migrate from soil to plants and animals along the food chain, so people was biggest victims because human is at the top of food chain ${ }^{[1]}$. It was reported that one fifth of cultivated soil was contaminated by heavy metal and cultivated soil of 25 districts in 11 province was contaminated by $\mathrm{Cd}^{[2,3]}$. Guangzhou revealed that $44.4 \%$ of rice and rice products contained $\mathrm{Cd}$ and the concentration exceeded standard in $2013^{[4]}$. Cd not only accumulated in the liver and kidney, but also bond with protein containing some functional groups such as hydroxyl, amino and sulfydryl which inhibited activity of enzyme and induce some disease such as Itai-itai disease ${ }^{[5,6]}$. At present, some methods were used to repair Cd-contaminated soil. Soil replacement decreased the Cd concentration of soil and seems to be most efficient, yet cost-prohibitive ${ }^{[7]}$. Soil washing is using some reagent to dissolve $\mathrm{Cd}$ in the soil and $\mathrm{Cd}$ in soil was removed by collecting solution containing $\mathrm{Cd}$. However, this method might cause second pollution, soil nutrient loss and damage of soil structure ${ }^{[8,9]}$. Phytoremediation is the most effective method to decrease concentration of heavy metals, but it cost a long time ${ }^{[10,11]}$. The situ immobilization of heavy metals could inhibit migration of heavy metals from soil to plant, so development of passivator was focused at present ${ }^{[12,13]}$. In order to prevent second pollution, it is important to develop environmental-friendly materials. This paper chose Bacillus mucilaginosus to modify illite which improved $\mathrm{Cd}$ adsorption of original illite. Adsorption capacity of $\mathrm{Cd}$ onto biological modified illite (BMI) in the solution was evaluated in the lab, the objective of this research is providing basis for practical application of BMI in Cd-contaminated soil. 


\section{MATERIALS AND METHODS}

\section{Materials}

Bacillus mucilaginosus was chosen to modified illite and modified method was showed as follows: The bacterium was inoculated in a $200 \mathrm{~mL}$ medium $(1 \mathrm{~L}$ medium containing $10.0 \mathrm{~g}$ sucrose, $0.3 \mathrm{~g}$ yeast extract, $0.5 \mathrm{~g}\left(\mathrm{NH}_{4}\right)_{2} \mathrm{SO}_{4}, 1.0 \mathrm{~g} \mathrm{~K}_{2} \mathrm{HPO}_{4}, 1.0 \mathrm{~g} \mathrm{MgSO}_{4} \cdot 7 \mathrm{H}_{2} \mathrm{O}$, and $0.5 \mathrm{~g} \mathrm{CaCO}$ in distilled water) and incubated at $30{ }^{\circ} \mathrm{C}$ on a shaker $(140 \mathrm{rpm})$ for $3 \mathrm{~d}$. The resultant culture served as start culture and was inoculated at $10 \%$ volume into $500 \mathrm{~mL}$ nitrogen-free medium $(1 \mathrm{~L}$ medium containing 5 g sucrose, $1.25 \mathrm{~g} \mathrm{Na}_{2} \mathrm{HPO}_{4} \cdot 12 \mathrm{H}_{2} \mathrm{O}, 0.5 \mathrm{~g} \mathrm{MgSO}_{4} \cdot 7 \mathrm{H}_{2} \mathrm{O}, 0.1 \mathrm{~g} \mathrm{CaCO}_{3}, 5.0 \mathrm{mg} \mathrm{FeCl}$, and $50 \mathrm{~g}$ illite in distilled water) and incubated at $30^{\circ} \mathrm{C}$ on a shaker $(140 \mathrm{rpm})$ for $7 \mathrm{~d}$. The culture was dried in drying oven and the solid was calcined at $400{ }^{\circ} \mathrm{C}$ in Muffle furnace for $2 \mathrm{~h}$, cooled in the air, then the solid and hydrogen peroxide were mixed uniformly and calcined at $200{ }^{\circ} \mathrm{C}$ in Muffle furnace, at last the solid was ground into 100 mesh and it was used as BMI.

\section{Experimental Design}

Adsorption of $\mathrm{Cd}$ onto different materials

Aqueous Cd solution $(50 \mathrm{~mL}, 20 \mathrm{mg} / \mathrm{L})$ was added to five $100 \mathrm{~mL}$ flasks and $0.2 \mathrm{~g}$ of different adsorption materials were placed to them, respectively. Three replications were performed. Each mixture was shaken at $30^{\circ} \mathrm{C}$ and $140 \mathrm{rpm}$ for $40 \mathrm{~min}$. Then, the solutions were filtered and the filtrate was used for Cd analysis.

Variation in Cd removal with adsorbent dosage

Aqueous Cd solution ( $50 \mathrm{~mL}, 20 \mathrm{mg} / \mathrm{L}$ ) was added to five $100 \mathrm{~mL}$ flasks and $0.1 \mathrm{~g}, 0.2 \mathrm{~g}, 0.4 \mathrm{~g}$, $0.6 \mathrm{~g}$, and $0.8 \mathrm{~g}$ of BMI were added to them, respectively. Three replications were performed. Each mixture was shaken at $30^{\circ} \mathrm{C}$ and $140 \mathrm{rpm}$ for $40 \mathrm{~min}$. Then, the solutions were filtered and the filtrate was used for Cd analysis.

Variation in Cd removal with $\mathrm{pH}$

Aqueous Cd solution $(50 \mathrm{~mL}, 20 \mathrm{mg} / \mathrm{L})$ was added to $100 \mathrm{~mL}$ flasks. Aqueous hydrochloric acid and potassium hydroxide were used to adjust the $\mathrm{pH}$ of each solution $(2.02,3.01,4.09,4.94,6.08$, 7.12 , 7.98). Then, BMI (0.1 g) was added to each flask and the subsequent operations were same with above.

\section{Adsorption isotherms}

Aqueous Cd solutions having different concentrations (5, 10, 20, 30, 40, and $50 \mathrm{mg} / \mathrm{L})$ were added to $100 \mathrm{~cm}^{3}$ flasks and BMI $(0.2 \mathrm{~g})$ were added to each. The mixtures were shaken at $30^{\circ} \mathrm{C}$ and 140 $\mathrm{rpm}$ for $40 \mathrm{~min}$. The solutions were filtered and the filtrates were used for $\mathrm{Cd}$ analysis. Three replications were carried out. Two models, involving the Langmuir and the Freundlich isotherms, were used to estimate the adsorptive capacity and adsorption equilibrium constant. The Langmuir and Freundlich isotherms could be expressed respectively in the forms:

$\frac{c_{e}}{q_{e}}=\frac{1}{q_{m} K_{L}}+\frac{c_{e}}{q_{m}} \quad \ln q_{e}=K_{F}+\frac{1}{n} \ln c_{e}$

where $c_{e}$ was the equilibrium concentration of the $\mathrm{Cd}(\mathrm{mg} / \mathrm{L}), q_{e}$ was the equilibrium amount of $\mathrm{Cd}$ adsorbed per unit mass of adsorbent $(\mathrm{mg} / \mathrm{g}), q_{m}$ was the adsorption capacity $(\mathrm{mg} / \mathrm{g}), n$ was a constant, and $K_{L}$ and $K_{F}$ were the Langmuir and Freundlich adsorption constants. 


\section{Adsorption kinetics}

Aqueous Cd solution $(500 \mathrm{~mL}, 20 \mathrm{mg} / \mathrm{L})$ and BMI $(2 \mathrm{~g})$ were placed in a $1 \mathrm{~L}$ flask. The mixture was shaken at $30^{\circ} \mathrm{C}$ and $140 \mathrm{rpm}$ for $40 \mathrm{~min}$. Samples $\left(10 \mathrm{~cm}^{3}\right)$ were subsequently collected at fixed time intervals $(5,10,15,20,40,60$ and $80 \mathrm{~min})$ to determine the change in the Cd concentration. The pseudo-second order kinetic model was written in the form:

$$
\frac{t}{q_{t}}=\frac{t}{q_{e}}+\frac{1}{k q_{e}^{2}}
$$

where $q_{e}$ and $q_{t}$ were the amounts $(\mathrm{mg} / \mathrm{g})$ of $\mathrm{Cd}$ adsorbed at equilibrium and at time $t$, respectively, and $k$ was the pseudo-second order rate constant.

\section{Statistical Analysis}

Data are expressed as the means \pm the standard errors (SD). Error bars in the figures represent \pm SD of triplicate samples. Control groups are the same in all cases.

\section{RESULTS AND DISCUSSIONS}

\section{Adsorption of Cd onto different materials}

Adsorption of $\mathrm{Cd}$ onto different materials was showed in Figure1. Cd removal of $\mathrm{I}_{1}$ was lowest among five materials $(63.27 \%)$. Cd removal of $\mathrm{I}_{2}(64.33 \%)$ was similar with $\mathrm{I}_{1}$, suggesting that direct calcination did not improve adsorption of $\mathrm{Cd}$ onto original illite. Organism in the culture was transformed into activated carbon in the process of calcination and the activated carbon existed in the pores of illite, hydrogen peroxide could oxidize carbon into carbon dioxide and released into air. $\mathrm{Cd}$ removal of $\mathrm{I}_{5}$ was higher than $\mathrm{I}_{4}$ showed that activated carbon produced in the process of calcination did not improve adsorption capacity of original illite. Adsorption of Cd onto $\mathrm{I}_{5}$ is highest because the interaction between microbes and minerals improved adsorption capacity of Cd onto illite. Cd removal of $\mathrm{I}_{3}$ was higher than that of $\mathrm{I}_{1}$, but lower than that of $\mathrm{I}_{5}$, the reason was that culture produced by B.mucilaginosus contained illite and the illite in the culture was modified to improve it's adsorption of $\mathrm{Cd}$. This result also proved that modification mechanism was the interaction between microbes and minerals.

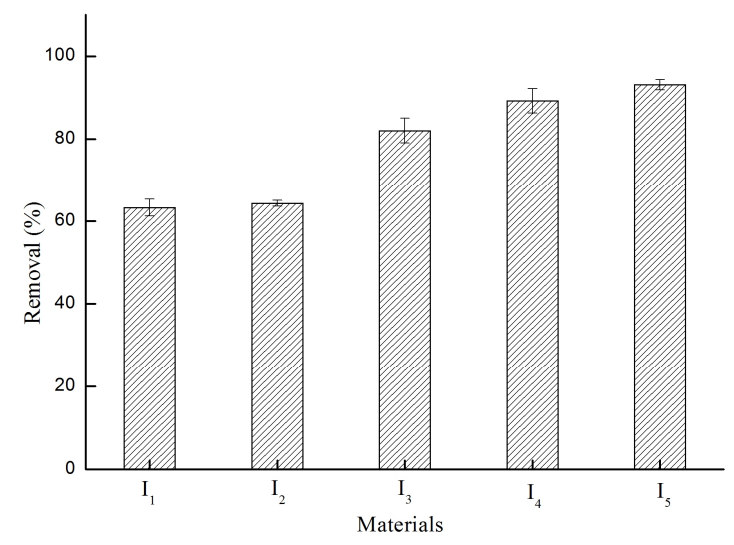

Figure 1. Adsorption of $\mathrm{Cd}$ onto different materials

Note: $\mathrm{I}_{1}$, original illite; $\mathrm{I}_{2}$, original illite was calcined at $400{ }^{\circ} \mathrm{C}$ in Muffle furnace; $\mathrm{I}_{3}$, the mixture of original illite and culture was calcined at $400{ }^{\circ} \mathrm{C}$ in Muffle furnace; $\mathrm{I}_{4}$, illite modified by B.mucilaginosus was calcined at $400{ }^{\circ} \mathrm{C}$ in Muffle furnace; $\mathrm{I}_{5}$, BMI. 


\section{Variation in Cd removal with adsorbent dosage}

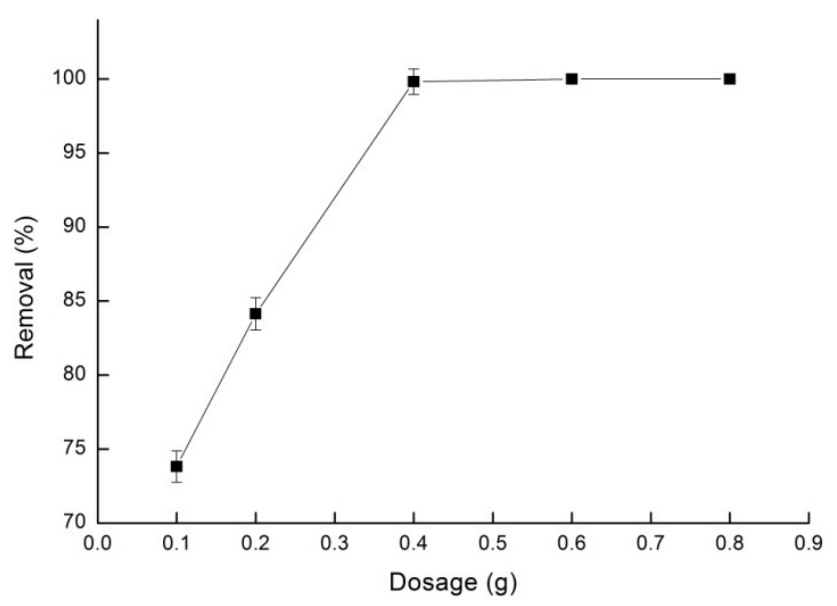

Figure 2. Variation in Cd removal with adsorbent dosage

The variation in the $\mathrm{Cd}$ removal efficiency with dosage was shown in Figure 2. When the dosage was $0.1 \mathrm{~g}$, the Cd removal efficiency from an aqueous solution $(50 \mathrm{~mL}, 20 \mathrm{mg} / \mathrm{L})$ was $87.46 \%$. Doubling the dosage to $0.2 \mathrm{~g}$ increased the removal efficiency to more than $89.90 \%$. Cd removal was about $100 \%$ when the dosage was above $0.4 \mathrm{~g}$. Therefore, the dosage was set to $4 \mathrm{~g}$ of adsorbent in $1 \mathrm{~L}$ of solution $(20 \mathrm{mg} / \mathrm{L})$ in subsequent experiments. As the above result showed, Cd removal did not reveal a linear increasing trend with the increase of dosage which might have a relationship with adsorption equilibrium. Initial Cd concentration was $20 \mathrm{mg} / \mathrm{L}$, so $\mathrm{Cd}$ concentration decreased with the increase of dosage of BMI and adsorption rate also decreased at the same time.

\section{The variation in $\mathrm{Cd}$ removal with $\mathrm{pH}$}

A change in $\mathrm{pH}$ might have a significant influence on the adsorption potential and thus we determine the optimum $\mathrm{pH}$ required for practical use. The change in $\mathrm{Cd}$ removal efficiency with $\mathrm{pH}$ was shown in Figure 3.

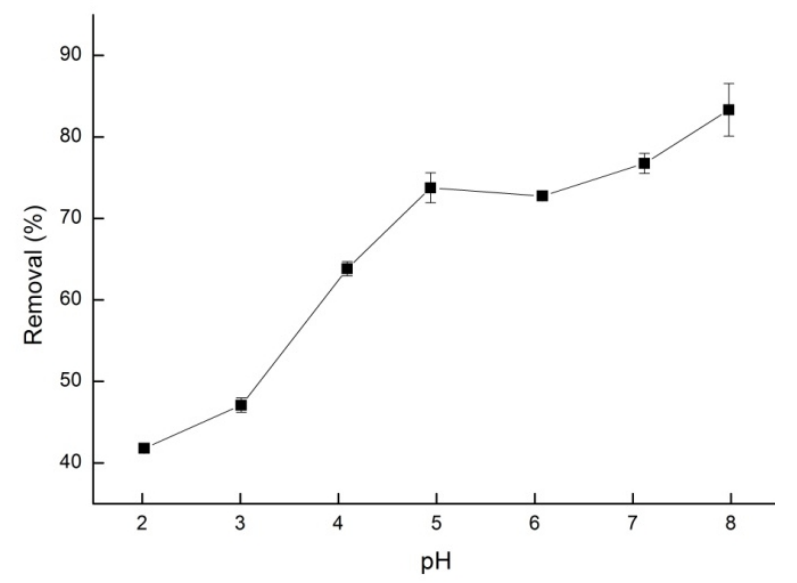

Figure 3. The variation in $\mathrm{Cd}$ removal with $\mathrm{pH}$

$\mathrm{Cd}$ removal increased with the increase of $\mathrm{pH}$. The removal of $\mathrm{Cd}$ was low when the $\mathrm{pH}$ was lower than 4.94. BMI charged negative, the ion strength of $\mathrm{H}^{+}$was higher than that $\mathrm{Cd}^{+}$in the acid environment, so $\mathrm{H}^{+}$would bind with BMI by charge neutralization and inhibit combination between BMI and $\mathrm{Cd}^{+}$. $\mathrm{Cd}$ removal was higher than $70.00 \%$ when the $\mathrm{pH}$ was between 4.94 and 7.98 , suggesting than BMI had a good adsorption in the neutral environment. When the $\mathrm{pH}$ was higher than $7.98, \mathrm{Cd}^{+}$bond with $\mathrm{OH}^{1-}$ and precipitated in the bottom of water, so higher $\mathrm{Cd}$ removal in alkaline environment did not show BMI had a good adsorption. 


\section{Adsorption isotherms}

The data obtained from adsorption isotherms were analysed by the Langmuir and Freundlich models. The Langmuir and Freundlich isotherms obtained using BMI were $c_{e} / q_{e}=0.209 c_{e}+0.041$ $\left(\mathrm{R}^{2}=0.9979\right)$ and $\ln q_{e}=1.2269+0.127 \ln c_{e}\left(\mathrm{R}^{2}=0.9910\right)$ respectively, so adsorption isotherms of $\mathrm{Cd}$ onto BMI followed Langmuir equation. The adsorption capacity of BMI was $4.78 \mathrm{mg} / \mathrm{g}$ which was higher than original illite $(1.09 \mathrm{mg} / \mathrm{g})$.

\section{Adsorption kinetics}

The variation in $\mathrm{Cd}$ concentration with time was showed in Figure 4. Adsorption of Cd onto BMI was divided into two stages. The first stage was fast adsorption, the $\mathrm{Cd}$ concentration decreased from $20.87 \mathrm{mg} / \mathrm{L}$ to $3.76 \mathrm{mg} / \mathrm{L}$ in the first minute and $\mathrm{Cd}$ removal was $81.96 \%$. This result showed than adsorption of $\mathrm{Cd}$ onto BMI might be physical adsorption. The second stage was slow adsorption, the concentration of $\mathrm{Cd}$ decreased from 3.76 to $1.45 \mathrm{mg} / \mathrm{L}$ and $\mathrm{Cd}$ removal was just $11.09 \%$. This adsorption might be induced by chemical adsorption and internal diffusion. The batch kinetic studies indicated that $\mathrm{Cd}$ adsorption onto BMI reaches equilibrium very quickly (less than $5 \mathrm{~min}$ ). The adsorption process was explained by the fact that the adsorption of Cd onto BMI involves a combination of physical and chemical adsorption.

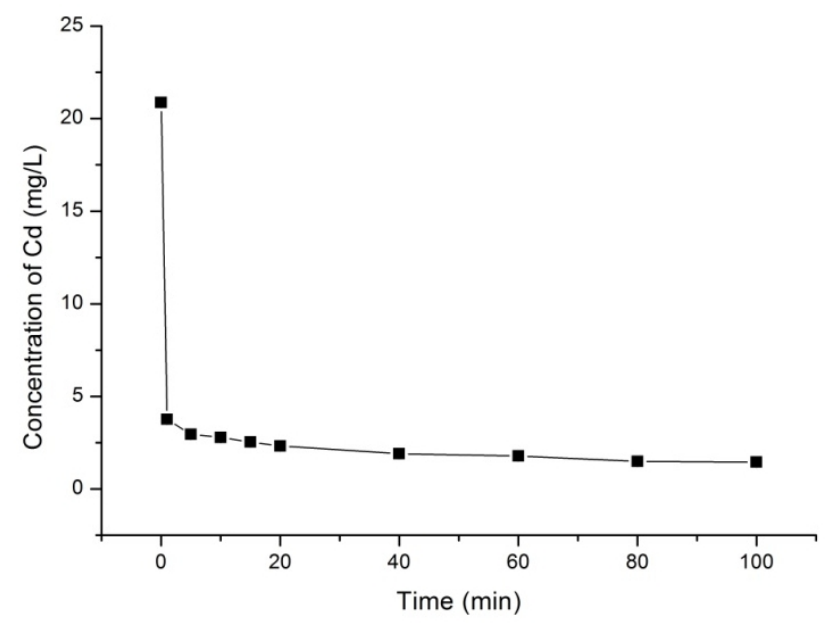

Fig 4. The variation in $\mathrm{Cd}$ concentration with time

Fitting the kinetic data to various mechanistic models, it appeared that a pseudo-second order kinetic equation best fited the adsorption data $\left(t / q_{t}=0.205 t+0.149\left(\mathrm{R}^{2}=0.996\right)\right)$ between 1 and $100 \mathrm{~min}$. The amounts of $\mathrm{Cd}$ adsorbed at equilibrium $\left(q_{e}\right)$ and pseudo-second order rate constant $(k)$ were $4.88 \mathrm{mg} / \mathrm{g}$ and $0.28 \mathrm{~g} \cdot \mathrm{mg}^{-1} \cdot \mathrm{min}^{-1}$. The pseudo-second order rate constant $(k)$ was small which proved slow adsorption between 1 and 100min. The best adsorption time was 40min and $\mathrm{Cd}$ removal was $90.91 \%$.

\section{CONCLUSIONS}

BMI had significantly improved Cd adsorption potential compared to original illite; BMI had a good adsorption in the neutral environment; adsorption isotherms of $\mathrm{Cd}$ onto BMI followed Langmuir equation and the maximum adsorption capacity was $4.78 \mathrm{mg} / \mathrm{g}$; adsorption kinetic of Cd on BMI followed pseudo-second order kinetic equation and the amounts of $\mathrm{Cd}$ adsorbed at equilibrium $\left(q_{e}\right)$ was $4.88 \mathrm{mg} / \mathrm{g}$. Fast adsorption of BMI and it's environmental friendly implied that the BMI has good prospects for application in practice. 


\section{ACKNOWLEDGEMENTS}

The study was supported by Sience and Technology Innovation Foundation of national College Students (201410061091) and Tianjin Science and Technology Support Program (13ZCZDSF02600).

\section{REFERENCES}

[1] RA Wuana, FE Okieimen. 2011 Heavy metals in contaminated soils: A review of sources, chemistry, Risks and best available strategies for remediation, ISRN Ecology, 2012:1-20.

[2] H Z Zhang, Y M Luo, H B Zhang, and etal. 2010 Study on soil environmental quality guidelines and standards $\mathrm{V}$. modeling of cadmium uptake in soil-crop systems for human food safety in china. ACTA Pedologica Sinica, 47(4): 628-638.

[3] X L Cao, Z Z Luo, DY Huang, etal. 2013 Effects of Cd-contaminated rice straw incorporation on transformation of Cd forms in soils. Journal of Agro-Environment Science, 32(9):1786-1792.

[4]http://www.gzfda.gov.cn/business/htmlfiles/gzfda/jdxw/201305/90190.html.2013.05.16.

[5] M MStorelli, and G. Barone. 2013 Toxic Metals (Hg, Pb, and Cd) in Commercially Important Demersal Fish from Mediterranean Sea: Contamination Levels and Dietary Exposure Assessment. Journal of Food Science, 8(2): 362-366

[6] M M Storelli, G Barone, G Cuttone, et al. 2010Occurrence of toxic metals $(\mathrm{Hg}, \mathrm{Cd}$ and $\mathrm{Pb})$ in fresh and canned tuna: Public health implications Food and Chemical Toxicology , 48(11): 3167-3170.

[7] Y B Zhu, L B Zhou, H Lin. 2010 Key technologies for compiling report of land reclamation plan for projects of metal mine. Nonferrous Metals, 62(2): 103-107.

[8] D Voglar, D Lestan. 2013 Pilot-scale washing of $\mathrm{Pb}, \mathrm{Zn}$ and Cd contaminated soil using EDTA and process water recycling. Chemosphere, 91(1):76-82.

[9] D Voglar, D Lestan. 2014 Chelant soil-washing technology for metal-contaminated soil. Environmental Technolgoy, 35(11):1389-1400

[10] H Ali, E Khan, MA Sajad. 2013 Phytoremediation of heavy metals-Concepts and applications. Chemosphere,91(7):869-881.

[11] Y Ma, M Rajkumar, Y Luo, et al. 2013 Phytoextraction of heavy metal polluted soils using Sedum plumbizincicola inoculated with metal mobilizing Phyllobacterium myrsinacearum RC6b. Chemosphere,93(7):1386-1392.

[12] Usman A, Kuzyakov Y, Stahr K. 2005 Effect of clay minerals on immobilization of heavy metals and microbial activity in a sewage sludge-contaminated soil. Journal of Soils and Sediments, 5(4):245-252.

[13] Y Sun, G Sun, Y Xu, etal. 2013 Assessment of sepiolite for immobilization of cadmium-contaminated soils. Geoderma,193:149-155. 